FROM THE SERVICE DE RADIOTHÉRAPIE (DIRECTOR: PROF. J. CLOSON), HÔPITAL UNIVERSITAIRE DE BAVIÈRE, B-4020 LIĖGE, BELGIUM.

\title{
ENHANCEMENT OF CONCOMITANT IMMUNITY AFTER RADIATION THERAPY AND IMMUNOTHERAPY IN A SYNGENEIC MURINE TUMOUR SYSTEM
}

\author{
J.-M. DENEUfBourg
}

The efficacy of radiation therapy of tumours depends on lethal effects on malignant cells but also on modifications of vessels and connective tissue (Stenström et coll. 1955, PUCK \& MARCUs 1956, HEWITT \& WILSON 1959). Tumour irradiation induces an immune response of the host cooperating in the destruction of allogeneic malignant cells (DeneufBourg 1972, 1975). These preliminary findings were tested in an experiment system consisting of a chemically induced epidermoid carcinoma transplanted in a syngeneic situation. The influence of irradiation and active non-specific immunotherapy was assessed in vivo on the level of concomitant immunity. The results are now reported.

\section{Materials and Methods}

Inbred female CBA mice 2 to 3 months old were used. They were fed with standard pellet diet and water ad libitum. The experiment groups contained 30 to 40 mice for each data point.

An epidermoid carcinoma was induced by repeated painting of the skin with 20-methylcholantrene, and a syngeneic tumour was maintained by serial subcutaneous transplantations. Tumour pieces aseptically prepared were inoculated intradermally in the median dorsal region of the animals. The tumour growth followed a linear progression and remained purely local without deep infiltration or visible metastases. Host mean survival time was about 30 days.
Irradiation was performed on day 8 of tumour growth. An original set-up of holding and shielding allowed a good exposure of the target volume without anesthesia (DENEUfBourG 1972). The irradiation was delivered through two parallel opposed portals and conferred single doses of 25 or $5 \mathrm{~Gy}$ at mid-depth. The radiation was generated with a Philips apparatus at $50 \mathrm{kV}$ and $2 \mathrm{~mA}$ with a $1 \mathrm{~mm} \mathrm{Al}$ filter and a focus-skin distance of $4 \mathrm{~cm}$. The wholebody dose did not exceed one per cent of the tumour dose.

Active non-specific immunotherapy. On day 8 of tumour growth $0.5 \mathrm{mg}$ of a suspension of Corynebacterium parvum ( $2 \mathrm{mg} / \mathrm{ml}$; kindly supplied by Institut Mérieux, Lyon, France) was injected intraperitoneally or subcutaneously in each animal.

Assessment of concomitant immunity. Three groups of mice (non-irradiated, irradiated, or after immunotherapy) bearing a dorsal tumour received a second intradermal tumour implant on their ventral side. This challenge graft contained about $10^{6}$ tumour cells; it was observed 3 times weekly and rejections were recorded.

\section{Results}

Tumour growth. After a latent period of at least 3 days anti-tumour immunization rose to 31 per cent on day 6 and to 73 per cent on day 8 . Then it

Accepted for publication 7 June 1982. 


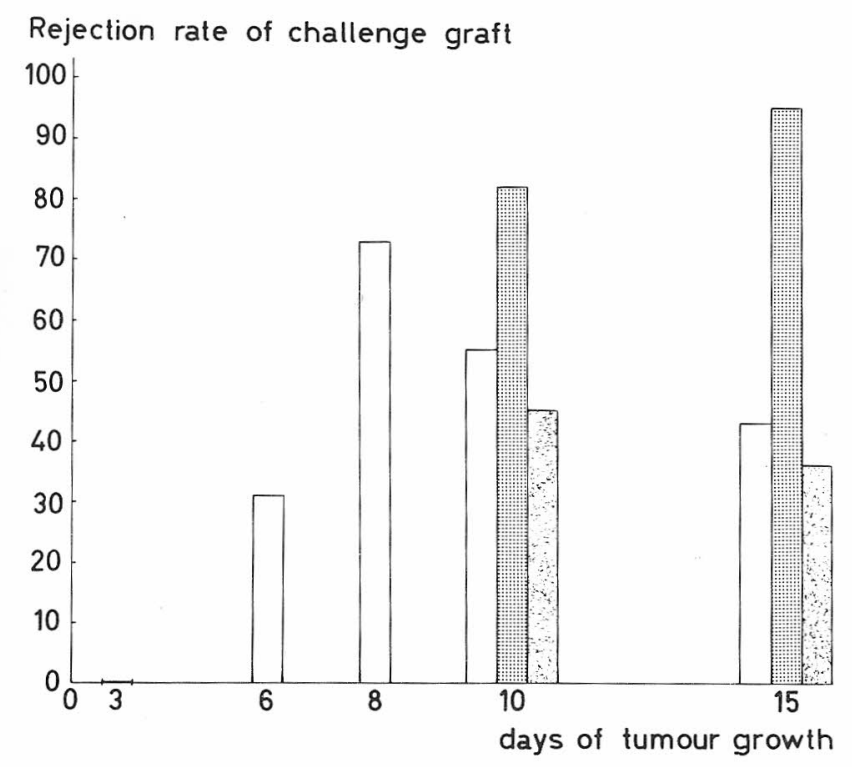

Fig. 1. Rejection rate of a challenge graft (in per cent) implanted on days $3,6,8,10$ and 15 of primary tumour growth and influence of radiation therapy (25 and 5 Gy tumour dose on day 8 ). No treatment ( $\square$ ). 25 Gy (앙). 5 Gy (图).

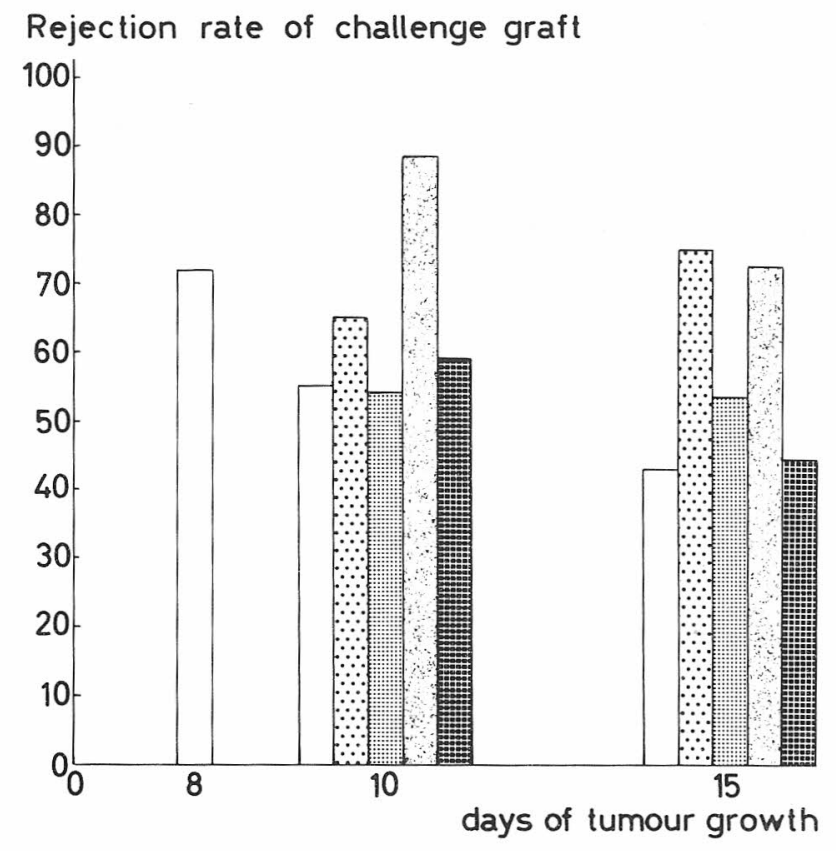

Fig. 2. Rejection rate of a challenge graft (in per cent) implanted on days 8,10 and 15 of primary tumour growth and influence of radiation therapy and immunotherapy $(5$ Gy tumour dose, intraperitoneal or subcutaneous injection of Corynebacterium parvum on day 8). No treatment ( $\square$ ). Corynebacterium parvum, intraperitoneally (@). Corynebacterium parvum, subcutaneously (․․). 5 Gy and Corynebacterium parvum, intraperitoneally (因). 5 Gy and Corynebacterium parvum, subcutaneously (:ii).

\section{Table}

Concomitant immunity during the growth of a syngeneic epidermoid carcinoma and influence of tumour irradiation and immunotherapy. Rejection rate of a challenge graft implanted on days 3, 6, 8, 10 and 15 of primary tumour progression. Treatment on day 8:25 Gy and 5 Gy tumour dose, intraperitoneal or subcutaneous injection of Corynebacterium parvum

\begin{tabular}{|c|c|c|c|c|c|}
\hline & \multicolumn{5}{|c|}{ Rejection rate of challenge graft } \\
\hline & Day 3 & Day 6 & Day 8 & Day 10 & Day 15 \\
\hline No treatment & $\begin{array}{c}0 \% \\
(0 / 34)\end{array}$ & $\begin{array}{c}31 \% \\
(11 / 35)\end{array}$ & $\begin{array}{l}73 \% \\
(22 / 30)\end{array}$ & $\begin{array}{l}55 \% \\
(21 / 38)^{a}\end{array}$ & $\begin{array}{l}43 \% \\
(15 / 35)^{b}\end{array}$ \\
\hline $25 \mathrm{~Gy}$ & - & - & $\begin{array}{l}73 \% \\
(22 / 30)\end{array}$ & $\begin{array}{l}82 \% \\
(31 / 38)^{a, c}\end{array}$ & $\begin{array}{l}95 \% \\
(38 / 40)^{b, d}\end{array}$ \\
\hline $5 \mathrm{~Gy}$ & - & - & $\begin{array}{c}73 \% \\
(22 / 30)\end{array}$ & $\begin{array}{l}45 \% \\
(17 / 38)^{c}\end{array}$ & $\begin{array}{l}36 \% \\
(14 / 39)^{d}\end{array}$ \\
\hline $\begin{array}{l}\text { Corynebacterium parvum, } \\
\text { intraperitoneally }\end{array}$ & - & - & $\begin{array}{c}73 \% \\
(22 / 30)\end{array}$ & $\begin{array}{l}65 \% \\
(26 / 40)^{f}\end{array}$ & $\begin{array}{l}75 \% \\
(24 / 32)^{e}\end{array}$ \\
\hline $\begin{array}{l}\text { Corynebacterium parvum, } \\
\text { subcutaneously }\end{array}$ & - & - & $\begin{array}{c}73 \% \\
(22 / 30)\end{array}$ & $\begin{array}{l}54 \% \\
(20 / 37)\end{array}$ & $\begin{array}{l}53 \% \\
(16 / 30)^{e}\end{array}$ \\
\hline $\begin{array}{l}5 \text { Gy and Corynebacterium parvum, } \\
\text { intraperitoneally }\end{array}$ & - & - & $\begin{array}{c}73 \% \\
(22 / 30)\end{array}$ & $\begin{array}{l}88 \% \\
(13 / 35)^{f, g}\end{array}$ & $\begin{array}{l}72 \% \\
(26 / 36)^{h}\end{array}$ \\
\hline $\begin{array}{l}5 \text { Gy and Corynebacterium parvum, } \\
\text { subcutaneously }\end{array}$ & - & - & $\begin{array}{c}73 \% \\
(22 / 30)\end{array}$ & $\begin{array}{l}59 \% \\
(22 / 37)^{g}\end{array}$ & $\begin{array}{l}44 \% \\
(15 / 34)^{h}\end{array}$ \\
\hline
\end{tabular}


gradually declined and the rejection rate fell to 55 per cent on day 10 and 43 per cent on day 15 (Table, Figs 1, 2).

Irradiation. The level of concomitant immunity increased after 25 Gy to 82 per cent 2 days later and to 95 per cent 7 days later, after 5 Gy the rejection rate of the challenge graft amounted to 45 per cent and 36 per cent, respectively.

Immunotherapy. After intraperitoneal administration of Corynebacterium parvum on day 8 of tumour growth concomitant immunity reached 65 per cent on day 10 and 75 per cent on day 15 . Using the subcutaneous route the corresponding rejection rates were 54 per cent and 53 per cent, respectively.

Immunotherapy and irradiation. A 5 Gy tumour dose associated with intraperitoneal injection of Corynebacterium parvum induced an 88 per cent rejection rate of the challenge graft on day 10 . Antitumour resistance evaluated on day 15 was present in 72 per cent of the mice. Results with adjuvant immunotherapy via the subcutaneous route were similar to the controls: 59 and 44 per cent, respectively.

\section{Discussion}

The efficacy of radiation therapy depends to a large extent on the lethal effects on tumour cells (PUCK \& MARCUS, HEWITT \& WilsON). Alterations of connective tissue and vascular modifications of the tumour bed are also known to play a part (STENSTRÖM et coll.).

Previously it was suggested that tumour irradiation induces an immune response of the host cooperating in the destruction of allogeneic malignant cells (DENEUfBOURG 1972, 1975). These preliminary results were confirmed in the present experiments using a chemically induced epidermoid carcinoma in a mouse syngeneic system.

An antigenic tumour while progressively growing induces an immunization of the host against additional tumour isografts (BASHFORD et coll. 1908). The level of this concomitant immunity reaches a maximum and then gradually declines as the primary tumour becomes larger (BARSKI \& YOUN 1969, DECKERS et coll. 1973). This phenomenon is related to several interacting factors: release of free antigen in excess, blockade by antigen-antibody complexes and production of suppressor lymphocytes and macrophages (BALDWIN et coll. 1972, THOMSON 1975, POUPON et coll. 1976).

According to the present results, tumour irradia- tion reverses the vanishing phase of concomitant immunity. A 25 Gy single dose was effective within 48 hours and conferred anti-tumour resistance to 95 per cent of the animals 8 days later. This reaction was dose related.

Data are still scarce in the literature about such immunologic effects. Fractionated tumour irradiation with a total dose of 90 to $120 \mathrm{~Gy}$ induced recovery of concomitant immunity in mice bearing a transplantable mammary tumour (BARSKI et coll. 1974). Reappearance of immune resistance against a fibrosarcoma was observed after a tumour dose of $60 \mathrm{~Gy}$ but was delayed as long as vascular connections between host and tumour persisted (VAAGE 1973). In both reports it was noted that a comparable level of immunity was achieved after surgery and that an incomplete tumour resection prevented full recovery. In the present system, irradiation did not lead to tumour elimination and yet reversed the decline of concomitant immunity without delay.

Mechanisms of radiation induced immune response are presently under investigation. Cell membrane destruction by irradiation is known to release antigenic material (MOROSON 1978). Irradiation may induce antigenic modifications or unmasking and enhance host immunization (MARUYAMA 1968). Untrapping of cytotoxic antibodies might also occur. Destruction of suppressor cells by whole-body exposure as a side-effect of tumour treatment is unlikely, due to the irradiation procedure.

Adjuvant active non-specific immunotherapy with Corynebacterium parvum counteracted the decline of concomitant immunity associated with tumour progression. Immunostimulation was effective within 48 hours and lasted 8 days at least. The discrepancy of activity between intraperitoneal and subcutaneous injections (CASTRO 1977) was confirmed. Irradiation at low dosage and Corynebacterium parvum acted synergistically. An irradiation with $5 \mathrm{~Gy}$ is unable to modify the tumour host balance but potentiates non-specific immunotherapy. Antigen availability may be a prerequisite for full range response to immunostimulation.

Detrimental immunosuppressive effects of radiation therapy have been pointed out especially in breast carcinoma treatment (STJERNSWÄRD 1974). However, the relations are perhaps more complicated than are presumed. The present results emphasize the fact that appropriate tumour irradiation and immunostimulation may also exert a beneficial influence on host resistance. 


\section{SUMMARY}

Concomitant immunity was evaluated in vivo towards a chemically induced epidermoid carcinoma transplanted in a syngeneic situation. Radiation therapy reversed the declining phase of concomitant immunity associated with tumour progression. The rejection rate of a challenge graft amounted to 82 and 95 per cent, respectively, 2 and 8 days after 25 Gy as compared with 55 and 43 per cent in unirradiated controls. Radiation induced immune recovery was dose related and proved to be different from restoration of immunity following surgical removal of the tumour. Immunotherapy with intraperitoneal injection of Corynebacterium parvum significantly improved concomitant immunity. Immunostimulation and irradiation at low dosage act synergistically on host anti-tumour resistance.

\section{ACKNOWLEDGEMENTS}

The author wishes to thank Mrs M. Evrard and Mr E. Pierard for their skilful technical assistance. This work was supported by a grant from the Fondation de Monsieur et Madame Braconier-Lamarche.

\section{REFERENCES}

BALDWIN R. W., PRICE M. R. and Robins R. A.: Blocking of lymphocyte-mediated cytotoxicity for rat hepatoma cells by tumor-specific antigen-antibody complexes. Nature New Biol. 238 (1972), 185.

BARSKI G. and Youn J. K.: Evolution of cell-mediated immunity in mice bearing an antigenic tumor. Influence of tumor growth and surgical removal. J. nat. Cancer Inst. 43 (1969), 111.

- - Lefrançois D. and BelehradeK J.: Evolution of specific cell-bound immunity in hosts bearing solid tumors as related to tumor growth and treatment. In: Immunological parameters of host-tumor relationship. Volume 3, p. 99. Edited by D. W. Weiss. Academic Press, New York, London 1974.

Bashford E. F., Murray J. A. and HaAland M.: General results of propagation of malignant new growth. Report Imperial Cancer Res. Fund. 3 (1908), 262.
CAstro J. E.: Effects of Corynebacterium parvum on tumour metastases in mice. Brit. J. Surg. 64 (1977), 721.

Deckers P. J., Davis R. C., Parker G. A. and Mannick J. A.: The effect of tumor size on concomitant tumor immunity. Cancer Res. 33 (1973), 33.

Deneufbourg J. M.: Radiothérapie tumorale et status immunitaire de l'hôte dans un système allogénique. Bull. Canc. 59 (1972), 61.

- Radiocurability of a transplantable murine sarcoma as influenced by immune competence of the host and adjuvant active specific immunotherapy. Strahlentherapie 149 (1975), 457.

HewitT H. B. and Wilson C. W.: A survival curve for mammalian leukemia cells irradiated in vivo. Implications for treatment of mouse leukemia by whole-body irradiation. Brit. J. Cancer 13 (1959), 69.

MARUYAMA Y.: Dose-dependent recognition of the irradiated isogenic mouse lymphoma. Study by terminal dilution assay. Int. J. Cancer 3 (1968), 793.

MoRoson H.: Migration inhibition of immune mouse spleen cells by serum from $\mathrm{X}$ irradiated tumor-bearing mice. Radiat. Res. 73 (1978), 192.

Poupon M. F., Kolb J. P. and Lespinats G.: Evidence for splenic suppressor cells in $\mathrm{C} 3 \mathrm{H} / \mathrm{HE}$ mice, T-cell deprived $\mathrm{C} 3 \mathrm{H} / \mathrm{HE}$ and nude mice bearing a 3-methylcholantrene induced fibrosarcoma. J. nat. Cancer Inst. 57 (1976), 1241.

Puck T. T. and MARCUS P. I.: Action of $\mathrm{X}$ rays on mammalian cells. J. exp. Med. 103 (1956), 653.

Stenström K. W., Vermund H., Mosser D. G. and MARVIN J. F.: Effect of roentgen irradiation in the tumor bed. The inhibiting action of local pretransplantation roentgen irradiation on the growth of mouse mammary carcinoma. Radiat. Res. 2 (1955), 180.

STJERNSWÄRD J.: Decreased survival correlated to local irradiation in early operable breast cancer. Lancet 2 (1974), 1285.

THOMSON D. M. P.: Soluble tumour-specific antigen and its relationship to tumour growth. Int. J. Cancer 15 (1975), 1016.

VAAGE J.: Influence of tumor antigen on maintenance versus depression of tumor specific immunity. Cancer Res. 33 (1973), 493. 